\title{
Biochemical characteristics of composite flours: influence of fermentation
}

\author{
Dogore Yolande DIGBEU ${ }^{1}$, Ahipo Edmond $\mathrm{DUE}^{2}$, Soumaila DABONNE ${ }^{2 *}$
}

\begin{abstract}
The purpose of this study was to introduce yam in the development of two new composite flours containing soy and cassava. Two composite flours were obtained after fermentation of yam, soybean, and cassava in respectively 60,30 , and $10 \%$ proportions. Two varieties of yam were used: Dioscorea alata (variety "Bete bete") and Dioscorea cayenensis (variety "Lokpa"). Proximate composition, mineral content, some anti-nutritional factors (oxalates, phenols), microbiological quality, and $\alpha$-amylase digestibility were determined for the fermented and unfermented composite flours. The results indicated that for the composite flours made of $D$. alata and D. cayenensis, fermentation increased ash and titrable acidity. Carbohydrates, $\mathrm{pH}$, and energy decreased. Crude fat content was not affected by the fermentation process. Anti-nutritional factors such as oxalates and phenols were found to decrease significantly after the fermentation of the composite flours. Fermentation increased the mineral content $(\mathrm{Mg}, \mathrm{K}, \mathrm{Fe}$, and $\mathrm{Ca}$ ) of the composite flours. A decrease in $\mathrm{P}$ and $\mathrm{Na}$ was observed after fermentation. The microbiological study showed that safety flours contain no potential pathogenic germs. The in vitro $\alpha$-amylase digestibility of the composite flours was significantly improved after fermentation. The biochemical characteristics and good hygienic quality of the obtained flours suggest that these flours can be considered as a feeding alternative for children in poor areas where yam is produced.
\end{abstract}

Keywords: infant food; tropical tuber; nutritional analysis; safety.

\section{Introduction}

Yams are members of the genus Dioscorea which contain about 600 species, of which only six are important in the tropics (COURSEY, 1969; HAHN et al., 1993). The economically important species grown are Dioscorea rotundata, D. alata, D. bulbifera, D. esculenta and D. dumenterum. Over $90 \%$ of world's yam production is derived from West Africa, especially from five yam zones, namely: Nigeria, Benin, Togo, Ghana, and Côte d'Ivoire. The crop is also widely cultivated in other parts of the world such as Asia, South America, South Pacific etc. (FOOD..., 1994).

The tubers of various species of Dioscorea constitute one of the stable carbohydrate foods for people in many tropical countries (AKISSOE et al., 2003). Many different forms and cultivars of the edible yam species are available in different areas, and it is likely that they differ in composition and nutritional values (BHANDARI; KAWABATA; KASAI, 2003).

Because of the low energy content of root crops compared to cereals on a wet basis, it is often assumed that root crops are not suitable for use as infant formula. This is not necessarily true if their energy density is increased by drying. Tapioca, for instance, is used in a number of commercial baby foods in industrialized countries. Composite flours prepared from root crops and cereals could also be used in baby food formulas if appropriately supplemented. Infants and young children, pregnant, and lactating women are among the most nutritionally vulnerable people. Their nutrient requirements are specifically higher in order to meet the increased physiological demand for growth and lactation (PICCIANO, 1998; ARMAR-KLEMESU et al., 1991).
Soybean has been widely used in human and animal nutrition because of its favourable agronomic characteristics, relatively low price, and high quantity and quality of its protein and oil (LIU, 2000). Moreover, consumers' awareness of the beneficial effects reported on health has increased its consumption (ALBERTAZZI, 2002; BUS; WORSLEY, 2003). Soybean has been widely used to improve the protein content of weaning foods in developing countries. Cassava (Manihot esculenta, Crantz) is largely used in human and animal nutrition, as well as raw material for several industrial products; the most important are the cassava flour, the cassava starch and the sour cassava starch (AVANCINI et al., 2007). Cassava root contains high levels of energy and has been used as a source of readily fermentable energy in ruminant rations (WANAPAT, 2003).

The edible, mature, cultivated yam does not contain any toxic principles. However, bitter principles tend to accumulate in immature tuber tissues of $D$. rotundata and $D$. cayenensis. They may be polyphenols or tannin like compounds (COURSEY, 1983). Several anti-nutritional factors are present in root and tuber crops. Enzyme inhibitors, e.g. against amylase and protease, occur in many tubers. The presence of these inhibitors could impair the digestion of starch and protein, thereby reducing the nutritional value of tubers and limiting their utilization as food (PRATHIBHA; BALA NAMBISAN; LEELAMMA, 1995). Oxalates and phytate are well known antinutrients of plant food, and they are associated with a decrease in bioavailability of nutritionally significant mineral elements. These organic substances can bind essential minerals to form insoluble or indigestible complexes in the lumen of intestinal

\footnotetext{
Received 1/9/2010

Accepted 6/5/2010 (004592)

${ }^{1}$ Laboratory of Nutrition and Food Security, University of Abobo-Adjamé-UAA, 02 BP 801, Abidjan 02, Côte d'Ivoire

${ }^{2}$ Laboratory of Biochemistry and Food Technology, University of Abobo-Adjamé - UAA, 02 BP 801, Abidjan 02, Côte d'Ivoire, e-mail: sdabonne@yahoo.fr

${ }^{*}$ Corresponding author
} 
tracts, thereby preventing their absorption (DAVIS; OLPIN, 1979). Nevertheless yam makes a significant contribution to diets of people due to its good nutritional value (BHANDARI; KAWABATA; KASAI, 2003). A simple process such as fermentation significantly reduces most of the anti-nutritional factors (REDDY; PIERSON, 1994; IHSAN et al., 2003; INYANG; ZAKARI, 2008). It is also one of the crops available throughout the year (SHIWACHI et al., 2008). Therefore, yam can be proposed as an interesting dietary supplement ingredient, particularly for young feeding. With regard to developing countries, the use of composite flours can bring the following advantages: promotion of high-yielding native plant species; a better supply of protein for human nutrition; a better overall use of domestic agriculture production (BUGUSU; CAMPANELLA; HAMBER, 2001)

The objective of this study is to develop new composite flours made of yam supplemented with cassava and soybean. Some of their biochemical characteristics will be determined.

\section{Materials and methods}

\subsection{Material}

For the experiments, two varieties of yam tubers from the species $D$. cayenensis rotundata and $D$. alata coming from different regions of Côte d'Ivoire (West Africa) were used. These varieties were "bete bete" for $D$. cayenensis rotundata and "lokpa" for D. alata. Cassava (Manihot esculenta Crantz) and white soybean (Glycine max) are also used as ingredients.

\subsection{Preparation of composite flours}

Yam tuber and cassava root was peeled and cut in pieces $(4 \times 4 \times 4 \mathrm{~cm})$ that were boiled separately for 30 minutes, and $200 \mathrm{~g}$ of the boiled pieces were processed in a blade mixer until dough like paste was formed. While yam past was immediately dried at $45^{\circ} \mathrm{C}$ for 48 hours, the obtained cassava past was pre-fermented for one day using a traditional starter (spontaneous fermented cassava flour) before drying. The typical microorganisms of traditional starters are the lactic acid bacteria with predominance of the genre Lactobacillus (L. plantarum, L. fermentum, $L$. delbrueckii and Lactobacillus L. manihotvorans) and yeasts and moulds (MORLON-GUYOT et al., 1998; LACERDA et al., 2005). A calibrated flour of cassava and yam was obtained after sieving with a $250 \mu \mathrm{m}$ sieve. Soybeans were cleaned, washed, soaked, and milled to obtain soy flour.

\subsection{Formulation of composite flours and fermentation process}

The composite flours are obtained by the mixing of flours made of yam, soybean, and cassava in respectively 60,30 , and $10 \%$ proportions in $100 \mathrm{~mL}$ of distilled water. The proportions $60 / 30 / 10$ were found to be the most equilibrated based on the preliminary sensory evaluation. The fermentation of the composite flour is initiated by inoculation with $8 \%(\mathrm{w} / \mathrm{w})$ of traditional starter (spontaneous fermented cassava flour). The fermentation process was done in anaerobic conditions for 48 hours at $30^{\circ} \mathrm{C}$. The fermented paste dried for 48 hours at $45^{\circ} \mathrm{C}$ gives the definitive yam based flour. Both fermented and unfermented yam based-flours were analysed for nutritional and safety value determination.

\subsection{Proximate analysis}

The moisture content and ash were determined in accordance with the standard methods of the AOAC (ASSOCIATION..., 1984). Titrable acidity and $\mathrm{pH}$ were determined using the AFNOR method (ASSOCIATION..., 1974). Crude fat was determined using the BIPEA method (BUREAU..., 1976) by exhaustively extracting samples in a Soxhlet apparatus using hexan as the solvent. Crude protein determination involved the use of routine Kjeldhal (BUREAU..., 1976) nitrogen assay ( $\mathrm{N} \times$ 6.25). Total sugars were removed by homogenizing compound flour in $80 \%$ ethanol (v/v). The homogenate was refluxed over a water bath and centrifuged. The residue was extracted twice more with $80 \%$ ethanol. The supernatant liquids were combined and used for estimation of soluble sugars by the method of Dubois et al. (1956). Calories were obtained by the summation of multiplied mean values for protein, fat and carbohydrate by their respective Atwater factors, 4, 9, and 4 (UDOSEN, 1995). All results for proximate composition are recorded on the basis of edible portion of the uncooked sample as $\mathrm{g} / 100 \mathrm{~g}$ dry weigh.

\subsection{Mineral analysis}

The minerals, such as calcium, copper, iron, magnesium, manganese, sodium, potassium, and zinc were analyzed after nitric acid digestion using an atomic absorption spectrophotometer (Model No. 560, Elmer Corp, Norwalk/ United States). Phosphorus was estimated colorimetrically (UV-visible spectrophotometer, Model DR 2800/United States). All results for mineral composition are recorded on the basis of edible portion of uncooked sample as $\mathrm{mg} / 100 \mathrm{~g}$ dry weight.

\subsection{Total phenols and oxalates}

One gram sample was extracted with $10 \mathrm{~mL}$ methanol $80 \%$ $(\mathrm{v} / \mathrm{v})$ containing formic acid $8 \%(\mathrm{v} / \mathrm{v})$. After 30 minutes, the mixed was centrifuged (3000 tours $/ \mathrm{min}$ ) for 10 minutes. The supernatant was diluted in a Folin-Ciocalteu solution containing one $\mathrm{mL}$ of sodium carbonate $17 \%(\mathrm{w} / \mathrm{v})$. The total phenols were determined spectrophotometrically as described by Swain and Hills (1959). Total oxalates were determined in accordance with the standard methods of the AOAC (ASSOCIATION..., 1984).

\subsection{Microbiology}

The samples were subjected to a microbiological analysis to monitor the population of potential pathogenic microorganisms during fermentation. Twenty-five grams of each sample were transferred into a sterile stomacher bag, $225 \mathrm{~mL}$ of salinepeptone water ( $8 \mathrm{~g}$ of $\mathrm{NaCl}$ per liter, $\mathrm{g}$ of bacterial peptone per liter from Sigma-Aldrich Inc.) was added, and the mixture was treated for 1.5 minute in a stomacher machine (Sigma-Aldrich Inc./Germany). Further decimal dilutions were made, and the following analyses were carried out on duplicate agar plates. Total aerobic mesophile flora was determined on plate count 
agar (Biochemika./United Kingdom) after incubation at $30^{\circ} \mathrm{C}$ for 72 hours; coliforms were counted on violet red bile agar (Sigma-Genosys./France).) after incubation at $30{ }^{\circ} \mathrm{C}$ for 24 hours; Staphylococcus aureus were numbered on Baird-Parker medium (Sigma-Aldrich Inc./Germany).) after incubation at $37^{\circ} \mathrm{C}$ for 48 hours; streptococci were counted on bile esculine azide (Biochemika/United Kingdom).) after incubation for 24 to 48 hours at $37^{\circ} \mathrm{C}$; Enteroccocci were numbered on citrate acide agar after incubation at $37^{\circ} \mathrm{C}$ for 72 hours. Yeasts and molds were isolated on malt extract agar (Ovoid) supplemented with tetracycline $(1 \mathrm{mg} / \mathrm{ml})$ (Sigma/France).) and incubated at $25^{\circ} \mathrm{C}$ for 72 hours. For salmonella, the International Organization for Standardization - ISO (1991) methods was performed. After counting, means and standard deviations were calculated.

\subsection{Digestibility}

The in vitro digestibility of flour was carry out using an a-amylase purified from Periplaneta americana according to the method of Kouame et al. (2004).

\subsection{Statistical procedure}

All determinations were carried out in triplicate for each nutrient analysis. For all analyses, the mean and standard deviation for each the nutrient analyzed were calculated and reported.

\section{Results and discussion}

\subsection{Proximate composition}

The proximate composition of unfermented and fermented composite flours is presented in Table 1. The moisture contents for Dioscorea alata based flour are 6.33 and $6.81 \%$ of dry weight respectively for unfermented (UFFDa) and fermented (FFDa) flour, respectively. The moisture contents of Dioscorea cayenensis based flours are $6.65 \%$ for unfermented flour (UFFDc) and $6.84 \%$ of dry weight for the fermented (FFDc) flour. The moisture contents of the composite flours were not affected after fermentation and drying. The values are in agreement with those generally reported for dried flours (EIMAN; AMIR; ABDEL, 2008).

The ash content of UFFDa is higher than that of UFFDc. While fermentation does not change ash content of composite flour made of Dioscorea cayenensis going from 2.53 to $2.62 \%$, it significantly increases the ash content of the one made of Dioscorea alata from 2.84 to $3.61 \%$.

The crude protein content of UFFD $a$ and UFFDc are respectively $15.21 \%$ and $13.83 \%$, while the fermented flours contain $15.66 \%$ and $15.30 \%$. The protein content increased significantly at the end of fermentation. This is mainly due to the reproduction of microorganisms and their metabolic activity during fermentation, as reported by previous studies. (HAYAT et al., 2008; INYANG; ZAKARI, 2008). Enzymatic proteins are produce by the lactic bacteria that represent the dominant microflora. They hydrolyze the starch of the composite flour leading to the production of sugar, lactic acids, acetaldehyde, diacetyl, peptides, and amino acids, which are precursors of flavor (AGBOR et al., 1995)

A decrease in the carbohydrate levels of the composite flours was observed with fermentation. The carbohydrates decreased from 8.46 to $5.92 \%$ for $\mathrm{FF} D a$ and from 12.20 to $8.50 \%$ for FFDc. This decrease might be due to the increase in alphaamylase activity (LASEKAN, 1996) during fermentation. The alpha-amylase breaks down complex carbohydrates to simple sugar. Energy values, 389.67 and $398.76 \mathrm{kcal} / 100 \mathrm{~g}$, of dry weight obtained respectively for $\mathrm{FFD} a$ and for $\mathrm{FFD} c$ were higher than those reported for yam (FOOD..., 1990).

The fermentation process did not significantly change the fat content of the composite flours obtained from both $D$. alata and $D$. cayenensis. Fermented flour made of $D$. cayenensis and D. alata contains respectively respectively 7.32 and $6.27 \%$ of crude fat. This relative high level is known to decrease shelf-life due to oxidation as noticed by Inyang and Idoko (2006) for a fermented meal made of pearl millet flour.

Fermentation remarkably decreased $\mathrm{pH}$ to 4.12 and 3.88 for flours made of $D$. alata and $D$. Cayenensis, respectively. Simultaneously with the drop in $\mathrm{pH}$, there was an increase in the titrable acidity for the two kinds of flour. Chavan and

Table 1. Proximate composition of the composite flour (g/100 g dry weight) $)^{\mathrm{a}}$.

\begin{tabular}{|c|c|c|c|c|}
\hline \multirow{2}{*}{ Parameters } & \multicolumn{2}{|c|}{ Dioscorea alata } & \multicolumn{2}{|c|}{ Dioscorea cayenensis } \\
\hline & UFFDa & $\mathrm{FFDa}$ & $\mathrm{UFFDc}$ & $\mathrm{FF} D c$ \\
\hline Dry matter & $93.37 \pm 0.03$ & $93.19 \pm 0.01$ & $93.35 \pm 0.025$ & $93.16 \pm 0.02$ \\
\hline Moisture & $6.33 \pm 0.011$ & $6.81 \pm 0.012$ & $6.65 \pm 0.022$ & $6.84 \pm 0.012$ \\
\hline Ash & $2.83 \pm 0.02$ & $3.61 \pm 0.022$ & $2.53 \pm 0.012$ & $2.63 \pm 0.018$ \\
\hline Crude protein & $15.21 \pm 0.02$ & $15.66 \pm 0.01$ & $13.83 \pm 0.00$ & $15.30 \pm 0.01$ \\
\hline Crude fat & $6.31 \pm 0.003$ & $6.27 \pm 0.001$ & $7.17 \pm 0.000$ & $7.32 \pm 0.002$ \\
\hline Carbohydrates & $8.46 \pm 0.02$ & $5.92 \pm 0.017$ & $12.20 \pm 0.011$ & $8.50 \pm 0.00$ \\
\hline $\mathrm{pH}$ & $6.5 \pm 0.01$ & $4.12 \pm 0.00$ & $6.3 \pm 0.01$ & $3.88 \pm 0.02$ \\
\hline Titrable Acidity & $0.06 \pm 0.011$ & $0.28 \pm 0.013$ & $0.05 \pm 0.02$ & $0.29 \pm 0.012$ \\
\hline Energy (kcal/100 g dry weight) & 476.350 .01 & $389.67 \pm 0.0$ & $502.31 \pm 0.01$ & $398.76 \pm 0.01$ \\
\hline
\end{tabular}

a: Values are the means of three determinations S.D. (n=3). UFFDa: unfermented flour made of Dioscorea alata; FFDa: fermented flour made of Dioscorea alata; UFFDc: unfermented flour made of Dioscorea cayenensis; FFDc: fermented flour made of Dioscorea cayenensis. 
Kadam (1989) stated that during fermentation, $\mathrm{pH}$ decreases with a concomitant increase in acidity as lactic acid accumulates due to microbial activity. During fermentation titrable acidity significantly increased from 0.06 to 0.28 and from 0.05 to 0.29 for FFD $a$ and FFDc, respectively. These results are in agreement with those of many researchers (HAMAD; FIELD, 1997; YOUSIF; EL-TINAY, 2001).

\subsection{Mineral composition}

The results of the mineral estimation of the wild yam tubers are presented in Table 2. Fermentation was observed to improve the content of most minerals. This is true for potassium, iron, calcium, and magnesium with respectively $4845.74,334.72,113.89$, and $120.5 \mathrm{~g} / 100 \mathrm{mg}$ of dry weight for fermented composite flours made of D. alata and 5380.98, $118.69,107.45$ and 257.89 for composite flours made of $D$. cayenensis. This result was consistent with those of Nnam (2000), who reported increases in iron, phosphorus, and calcium following germination of hungary rice (acha). In this study, only two mineral (phosphorus and sodium) contents decreased after fermentation, which is also in agreement with the results reported by Rendlemen (1982) and Pomeranz and Gain (1983). These authors monitored mineral composition of composite cereal flours.

\subsection{Total phenols and oxalates}

The unfermented composite flours of D. alata and $D$. cayenensis contain respectively 95.44 and $105.66 \mu \mathrm{g} / \mathrm{g}$ of dry matter of total phenols. The analysis of the results shows significant effect of the fermentation process. There was a decrease in total phenols levels after fermentation (Figure 1). After 48 hours of fermentation of the two composite flours, about $39.48 \%$ and $50.92 \%$ loss of total phenols was noted respectively for flour made of $D$. alata and $D$. cayenensis. A similar effect has been reported in an earlier study, in which $48 \%$ loss of phenolic compounds was found after 14 day fermentation of $D$. dumetorum hardened tubers (MEDOUA et al., 2008).

Oxalates appear as end-metabolism products in many vegetable tissues. When they are consumed, oxalates can link calcium and other minerals (NOONAN; SAVAGE, 1999). UFF $D a$ and UFF $D c$ contained 2.28 and $3.31 \mathrm{mg} / 100 \mathrm{~g}$ of dry matter of oxalates. A decrease in oxalate levels was noted after the fermentation process (Figure 2). Around $58.08 \%$ and $66.17 \%$ loss of oxalates was noted after 48 hours of fermentation of flours made of $D$. alata and $D$. Cayenensis, respectively. The decreases in oxalate levels observed in this study can be imputed to their solubility in the soak water since it is known that soaking decreases oxalate levels in food by leaching (NOONAN; SAVAGE, 1999; MEDOUA et al., 2008).

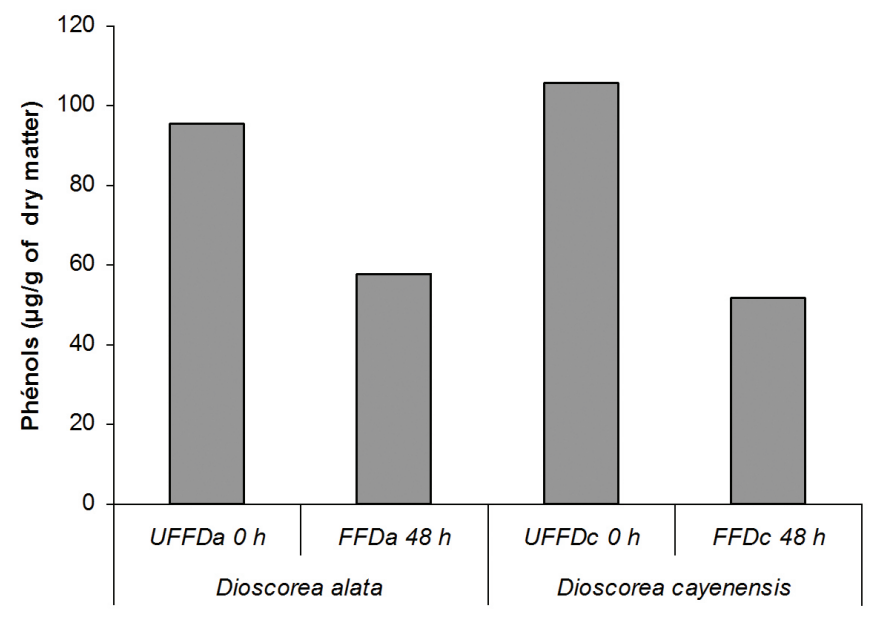

Figure 1. Influence of fermentation on total phenols content. UFFDa: unfermented flour made of Dioscorea alata; FFDa: fermented flour made of Dioscorea alata; UFFDc: unfermented flour made of Dioscorea cayenensis; FFDc: fermented flour made of Dioscorea cayenensis.

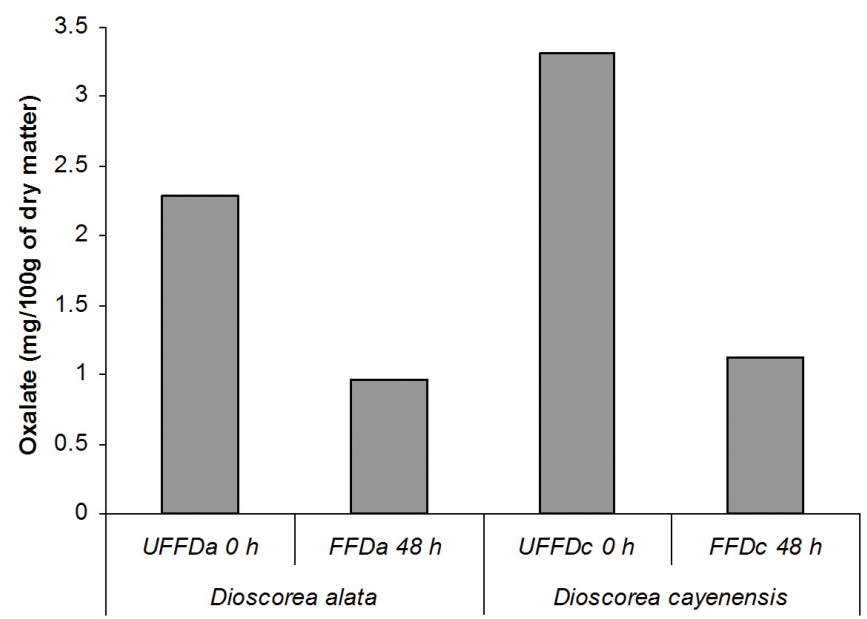

Figure 2. Influence of fermentation on total oxalates content. UFFDa: unfermented flour made of Dioscorea alata; FFDa: fermented flour made of Dioscorea alata; UFFDc: unfermented flour made of Dioscorea cayenensis; FFDc: fermented flour made of Dioscorea cayenensis.

Table 2. Mineral composition of the composite flours (mg/100 g dry weight).

\begin{tabular}{ccccc}
\hline \multirow{2}{*}{ Minerals } & \multicolumn{2}{c}{ Dioscorea alata } & \multicolumn{2}{c}{ Dioscorea cayenensis } \\
\cline { 2 - 5 } & UFFDa & FFDa & UFFDc & $157.82 \pm 0.012$ \\
$\mathrm{Mg}$ & $18.17 \pm 0.02$ & $120.50 \pm 0.01$ & $4525.49 \pm 0.01$ & $538.89 \pm 0.02$ \\
$\mathrm{~K}$ & $4699.25 \pm 0.01$ & $4845.74 \pm 0.01$ & 76.250 .0025 & 55.840 .0031 \\
$\mathrm{P}$ & 51.440 .003 & 28.390 .0012 & $13.43 \pm 0.02$ & $12.33 \pm 0.017$ \\
$\mathrm{Fe}$ & $15.14 \pm 0.014$ & $4.18 \pm 0.012$ & $102.48 \pm 0.055$ & $118.69 \pm 0.074$ \\
$\mathrm{Ca}$ & $113.39 \pm 0.045$ & $334.72 \pm 0.063$ & $65.76 \pm 0.27$ & $107.45 \pm 0.17$ \\
\hline
\end{tabular}

a: Values are the means of three determinations_S.D. (n=3). UFFDa: unfermented flour made of Dioscorea alata; FFDa: fermented flour made of Dioscorea alata; UFFDc: unfermented flour made of Dioscorea cayenensis; FFDc: fermented flour made of Dioscorea cayenensis. 


\subsection{Microbiology of fermented flours}

Microbiological analysis of fermented and unfermented flours was mainly focused on the search for potentially pathogenic microorganisms. S. aureus, coliforms, Streptococci, Enteroccocci, Salmonella were not detected (Table 3). These results are in good agreement with those found by Parveen and Hafiz (2003) on fermented cereal from indigenous raw materials. The manipulator and the traditional starter are potential sources of contamination of composite flours. The good hygienic quality of obtained flours highlights the safety of the traditional starter and good manufacturing practices.

\subsection{Digestibility}

In vitro digestibility of composite flours is affected by fermentation. $a$-amylase in vitro digestibility of composite flours are increased in fermented flours. Values of $\alpha$-amylase digestibility of UFFD $a$ and FFD $a$ increased from 56.9 to $85.3 \%$

Table 3. Microbiology of fermented composites fours.

\begin{tabular}{lcccc}
\hline & \multicolumn{2}{c}{$\begin{array}{c}\text { Dioscorea } \\
\text { alata }\end{array}$} & \multicolumn{2}{c}{$\begin{array}{c}\text { Dioscorea } \\
\text { cayenensis }\end{array}$} \\
\hline Micro & UFFDa & $\mathrm{FFDa}$ & $\mathrm{UFFDc}$ & $\mathrm{FFDc}$ \\
Total aerobic count $<3000 / \mathrm{g}$ & 30000 & 30000 & 30000 & 30000 \\
Coliform $<1000 / \mathrm{g}$ & $\mathrm{nf}$ & $\mathrm{nf}$ & $\mathrm{nf}$ & $\mathrm{nf}$ \\
S. aureus $<1000 / \mathrm{g}$ & $\mathrm{nf}$ & $\mathrm{nf}$ & $\mathrm{nf}$ & $\mathrm{nf}$ \\
Streptococci $<1000 / \mathrm{g}$ & $\mathrm{nf}$ & $\mathrm{nf}$ & $\mathrm{nf}$ & $\mathrm{nf}$ \\
Enteroccocci $<1000 / \mathrm{g}$ & $\mathrm{nf}$ & $\mathrm{nf}$ & $\mathrm{nf}$ & $\mathrm{nf}$ \\
Salmonella absence in $25 \mathrm{~g}$ & $\mathrm{nf}$ & $\mathrm{nf}$ & $\mathrm{nf}$ & $\mathrm{nf}$ \\
Yeasts $<100 / \mathrm{g}$ & $\mathrm{nc}$ & $\mathrm{nc}$ & $\mathrm{nc}$ & $\mathrm{nc}$ \\
Molds $<1 / \mathrm{g}$ & $\mathrm{nc}$ & $\mathrm{nc}$ & $\mathrm{nc}$ & $\mathrm{nc}$ \\
\hline
\end{tabular}

nf: not found, nc: not counted; UFFDa: unfermented flour made of Dioscorea alata; FFDa: fermented flour made of Dioscorea alata; UFFDc: unfermented flour made of Dioscorea cayenensis; FFDc: fermented flour made of Dioscorea cayenensis.

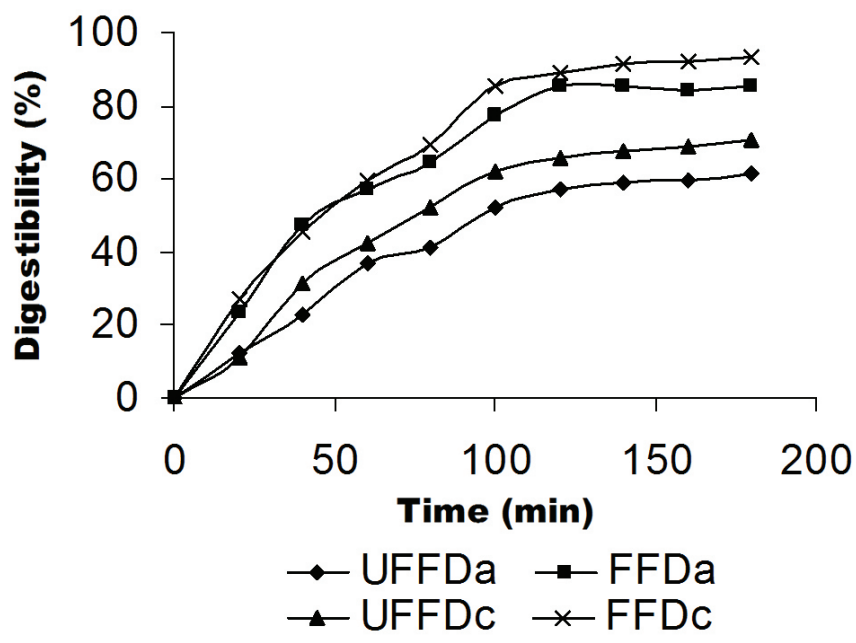

Figure 3. In vitro digestibility of composite fermented and unfermented flours made of Dioscorea alata and Dioscorea cayenensis. UFFDa: unfermented flour made of Dioscorea alata; FFDa: fermented flour made of Dioscorea alata; UFFDc: unfermented flour made of Dioscorea cayenensis; FFDc: fermented flour made of Dioscorea cayenensis. after 120 hours of digestion. For UFF $D c$ and FFDc, digestibility is improved from 65.5 to $88.5 \%$. Digestibility of fermented flour made of $D$. cayenensis is higher than that of flour made of $D$. alata (Figure 3). The fermentation process was also observed to improve in vitro digestibility of sorghum (Sorghum bicolor L. Moench) flour supplemented with Cluster bean (Cyamopsis tetragonolaba L.) (ELBASHIR et al., 2008).

\section{Conclusion}

This study shows that yam can be successfully introduced in the formulation of composite flours, which are low cost and easy to prepare. This is a new method of valuing this very important crop in the diets of vulnerable people such as children in poor regions but which produce large quantities of yam. The stability of the obtained flours should be further studied.

\section{References}

AGBOR, E. T. et al. The effectiveness of cyanogens reduction during cassava processiong into miondo. In: AGBOR, E. et al. (Eds.). Transformation Alimentaire du manioc. Paris: Orstom, 1995. p. 307-318.

AKISSOE, N. et al. How blanching and drying affect the colour and functional characteristics of yam (Dioscorea cayenensis- rotundata) flour. Food Chemistry, v. 82, n. 2, p. 257-264, 2003. http://dx.doi. org/10.1016/S0308-8146(02)00546-0

ALBERTAZZI, P. Clinical use of products. International Congress Series, v. 1229, p. 189-193, 2002. http://dx.doi.org/10.1016/S05315131(01)00488-5

ARMAR-KLEMESU, M. A. et al. Infant feeding and growth in rural Ghana: is the use of the traditional fermented porridge a case for early supplementation? Journal of Tropical Pediatrics, v. 37, n. 3, p. 111-115, 1991. http://dx.doi.org/10.1093/tropej/37.3.111

ASSOCIATION FRANÇAISE DE NORMALISATION - AFNOR. Products derived from fruits and vegetables. Determination of titratable acidity. Paris: AFNOR NF, 1974. v. 05-101, p. 1-4.

ASSOCIATION OF OFFICIAL ANALYTICAL CHEMISTS - AOAC. In official Methods of Analysis. 14th ed. Washington: AOAC, 1984.

AVANCINI, S. R. P. et al. Cassava starch fermentation wastewater : Characterization and preliminary toxicological studies. Food and Chemical Toxicology, v. 45, p. 2273-2278, 2007. PMid:17637494. http://dx.doi.org/10.1016/j.fct.2007.06.006

BHANDARI, M. R.; KAWABATA, J.; KASAI, T. Nutritional evaluation of wild yam (Discorea spp.) tubers of Nepal. Food Chemistry, v. 80, p. 619-623, 2003. http://dx.doi.org/10.1016/S0308-8146(03)00019-0

BUGUSU, B. A.; CAMPANELLA, O.; HAMBER, B. R. Improvement of sorghum-wheat composite dough rheological properties and breadmaking quality through zein addition. Cereal Chemestry, v. 78, n. 1, 2001.

B UREAU INTERPROFESSIONNEL D'ETUDE ANALYTIQUE - BIPEA. Recueil des méthodes d'analyse des communautés Européennes. BIPEA, 1976. 110 p.

BUS, A. E. M.; WORSLEY, A. Consumers' health perception of three types of milk: A survey in Australia. Appetite, v. 40, n. 2, p. 93-100, 2003. http://dx.doi.org/10.1016/S0195-6663(03)00004-7

CHAVAN, J. K.; KADAM. Nutritional improvement of cereals by sprouting. Critical Reviews in Food Science and Nutrition, v. 28, n. 2, p. 401-437, 1989. PMid:2692609. http://dx.doi. org/10.1080/10408398909527508 
COURSEY, D. G. Ascorbic Acid in Ghana Yams. Journal of Food Science and Agriculture, v. 17, p. 446-449, 1969. http://dx.doi. org/10.1002/jsfa.2740171003

COURSEY, D. G. Yams. In: CHAN, H. T. (Ed.). Handbook of tropical foods. New York: Dekker, 1983. p. 555-601.

DAVIS, N. T.; OLPIN, S. Studies on the phytate: Zn molar content in diet as a determinant of zinc availability to young rats. British Journal of Nutrition, v. 41, p. 591-603, 1979. http://dx.doi. org/10.1079/BJN19790074

DUBOIS, M. et al. Analytical Chemistry. 1956. v. 28, 250 p.

EIMAN, G. H.; AMIR, M. A. A.; ABDEL, M. I. M. Effect of fermentation and particle size of Wheat Bran on the Antinutritional Factors and Bread Quality. Pakistan Journal of Nutrition, v. 7, n. 4, p. 521-526, 2008. http://dx.doi.org/10.3923/pjn.2008.521.526

ELBASHIR, H. Z. et al. Biochemical characteristics of sorghum (Sorghum bicolour L.) flour supplemented with cluster bean (Cyamopsis tetragonolaba L.): Influence of fermentation and/or cooking. Journal of Biological Sciences, v. 8, n. 4, p. 722-729, 2008. http://dx.doi.org/10.3923/jbs.2008.722.729

FOOD AND AGRICULTURE ORGANIZATION OF THE UNITED NATIONS - FAO. Roots, tubers, plantains and bananas in human nutrition. Rome: FAO, 1990. 43 p. (FAO and Food Nutrition series, n. 24).

FOOD AND AGRICULTURE ORGANIZATION OF THE UNITED NATIONS - FAO. Production Statistics. Rome: FAO, 1994. v. 48, p. 265.

HAHN, S. K. et al. Production of Yams, Present Role and Future Prospects. IITA Ibadan, 1993. p. 36. (IITA Research Guide, n. 46).

HAMAD, A. M.; FIELD, M. L. Evaluation of the protein quality and available lysine of germinated and fermentated cereals. Journal of Food Science, v. 44, n. 2, p. 456-459, 1997. http://dx.doi. org/10.1111/j.1365-2621.1979.tb03811.x

HAYAT, Z. E. et al. Biochemical characteristics of Sorghum (Sorghum bicolour L. Moench) flour supplemented with cluster bean (Cyamopsis tetragolaba L.): Influence of fermentation and or cooking. Journal of Biological Sciences, v. 8, n. 4, p. 722-729, 2008. http://dx.doi.org/10.3923/jbs.2008.722.729

IHSAN, M. Q. et al. Effect of different time and baking on phytic acid content of whole-wheat flour bread. Asian Journal of Plant Science, v. 2, n. 8, p. 597-601, 2003. http://dx.doi.org/10.3923/ ajps.2003.597.601

INYANG, C. U.; IDOKO, C. A. Assessment of the quality of "ogi" made from malted millet. African Journal of Biotechnology, v. 5, 2334-2337, 2006.

INYANG, C. U.; ZAKARI, U. M. Effect of Germination and fermentation of Pearl millet on proximate, chemical and sensory properties of instant "Fura"- a Nigerian cereal food. Pakistan Journal of Nutrition, v. 7, n. 1, p. 9-12, 2008. http://dx.doi. org/10.3923/pjn.2008.9.12

I N T E R N A T I O N A L O R G A N I S A T I O N F O R STANDARDIZATION - ISO. Microbilogy general guidance on methods for the detection of Salmonella. Draft international ISO/ DIS 6579. Geneva: ISO, 1991.

KOUAME, P. L. et al. Synergism of cockroach (Periplaneta americana) $\alpha$-amylase and $\alpha$-glucosidase hydrolysis of starches. African Journal of Biotechnology, v. 3, n. 10, p. 529-533, 2004.

LACERDA, I. C. A. et al. Lactic acid bacteria and yeasts associated with spontaneous fermentations during the production of sour cassava starch in Brazil. International Journal of Food
Microbiology, n. 105, p. 213-219, 2005. PMid:16153731. http:// dx.doi.org/10.1016/j.ijfoodmicro.2005.04.010

LASEKAN, O. O. Effects of germination on alpha-amylase activities and rheological properties of sorghum (Sorghum biocolar) and acha (Digitaria exilis) grains. Journal of Food Science and Technology, v. 33, p. 329-331, 1996

LIU, K. Expanding soybean food utilization. Food Technology, v. 7 , n. 54, p. $46-58,2000$

MEDOUA, G. N. et al. Influence of fermentation on some quality characteristics of trifoliate yam (Dioscorea dumetorum) hardened tubers. Food Chemistry, v. 107, p. 1180-1186, 2008.

MORLON-GUYOT, J. et al. Lactobacillus manihotvorans sp. Nov; a new starch-hydrolysing lactic acid bacterium isolated during cassava sour starch fermentation. International Journal of systematic bacteriology, v. 48, p. 1101-1109, 1998. http://dx.doi. org/10.1099/00207713-48-4-1101

NNAM, N. M. Evaluation of effect of sprouting on the viscosity, proximate composition and mineral content of hungary rice, acha (Digiteria exilis) flours. Nigerian Food Journal, v. 18, p. 57-62, 2000.

NOONAN, S. C.; SAVAGE, G. P. Oxalate content of food and its effect on humans. Asia Pacific Journal of Clinical Nutrition, v. 1, p. 64-74, 1999.

PARVEEN, S.; HAFIZ, F. Fermented cereal from indigenous raw material. Pakistan journal of nutrition, v. 2, n. 5, p. 289-291, 2003.

PICCIANO, M. F. Human milk: nutritional aspects of a dynamic food. Biology of the Neonate, v. 74, n. 2, p. 84-93, 1998. PMid:9691151. http://dx.doi.org/10.1159/000014015

POMERANZ, Y.; GAIN, U. S. Mineral in protein content hard red winter wheat. Journal of cereal Chemistry, v. 60, p. 80-81, 1983.

PRATHIBHA, S.; BALA NAMBISAN; LEELAMMA, S. Enzyme inhibitors in tuber crops and their thermal stability. Plant Foods for Human Nutrition, v. 48, p. 247-257, 1995. PMid:8833431. http:// dx.doi.org/10.1007/BF01088446

REDDY, N. R.; PIERSON, M. D. Reduction in antinutritional and toxic components in plant foods by fermentation. Food Research International, v. 27, p. 181-190, 1994. http://dx.doi. org/10.1016/0963-9969(94)90096-5

RENDLEMEN, J. A. Cereal complexes : Binding Calcium by bran and components of bran. Journal of Cereal Chemistry, v. 59, p. 302309, 1982.

SHIWACHI, H. et al. Enhancing off-season yam production in Nigeria. African Journal of Agricultural Research, v. 3 n. 6, p. 407-411, 2008.

SWAIN, T.; HILLIS, W. E.The phenolic constituents of Prunes domestica I. The quantitative analysis of phenolic constituents. Journal of the Science of Food and Agriculture, v. 10, p. 63-68, 1959. http://dx.doi.org/10.1002/jsfa.2740100110

UDOSEN, E. O. Proximate and mineral composition of some Nigerian vegetable. Discovery and Innovation v. 7, n. 4, p. 383-386, 1995.

WANAPAT, M. Manipulation of cassava cultivation and utilization to improve protein to energy biomass for livestock feeding in the tropics. Asian - Australasian Journal of Animal Sciences, v. 16, p. 463-472, 2003.

YOUSIF, N. E.; EL-TINAY, A. H. Effects of fermentation on sorghum protein fractions and in vitro protein digestibility. Plant Foods for Human Nutrition, v. 56, n. 1, p. 175-182, 2001. PMid:11318506. http://dx.doi.org/10.1023/A:1011140602122 